\title{
PERFORMANCE ANALYSIS OF SKIPJACK TUNA SUPPLY CHAINS IN ACEH LAMPULO JAYA BAHARI LTD
}

\author{
Husna Naziratil, Indra*, Deli Anwar \\ Faculty of Agriculture, Syiah Kuala University, Indonesia \\ *E-mail: indrazainun@unsyiah.ac.id
}

\begin{abstract}
Raw material management in the Skipjack Tuna fishing industry is important to be considered due to its abundant stock. The success of a business is not only measured by the level of production and profits, but the cooperative partnership must also be considered in the supply chain system. The purpose of this study was to determine the product flow, financial flow and information flow of Skipjack Tuna supply at Aceh Lampulo Jaya Bahari Ltd. and to determine its performance at Aceh Lampulo Jaya Bahari Ltd. The descriptive analysis method was employed to analyze product flow, financial flow and information flow. This research used the Supply Chain Operation Reference (SCOR) to measure supply chain performance. Performance measurements on the SCOR matrix in this study are supported by the Analytical Hierarchy Process (AHP) and Objective Matrix (OMAX) methods. The results showed that the product flow, information flow and financial flow at Aceh Lampulo Jaya Bahari Ltd. were still not optimal due to the lack of planned raw material supply, inadequate information flow and financial flow with too long waiting periods. The results showed that are $5 \mathrm{KPIs}$ which categorized poor namely P.R.1, S.F.1, M.R.2, M.R.3 and M.C.1. The total performance value of Aceh Lampulo Jaya Bahari Ltd. is in the average category with a total index value reaching 64.2.
\end{abstract}

\section{KEY WORDS}

Supply chain, supply chain performance, SCOR, OMAX, Skipjack Tuna.

The importance of knowing Skipjack Tuna supply chain system is to reduce the risk of uncertainty, both in the form of production and distribution (Sutrisno et al, 2019). The supply chain is an integrated cooperative relationship or an effort to connect to each other that aims to add value to the output that involves several stakeholders to reach the best profit (Husna, 2018). The supply chain system not only measures the success of a business based on the level of production and profits, but also consider the cooperative relationship between stakeholders involved, so that the implementation of the supply chain system can be optimal (Kasimin, 2013). The management of raw materials in the Skipjack Tuna fishing industry is important to be concerned due to its abundant stock (Sulaeman et al, 2018). Skipjack Tuna commodity is a type of fish that has high economic value and plays an important role in the regional and national economy (Toding et al, 2019).

Aceh's ocean has considerable potential for fish resources (Athaillah, 2018). Aceh has a sea area of $295,370 \mathrm{Km}^{2}$ with a coastline of $2,666 \mathrm{Km}$. With such a vast sea area, Aceh's fishery potential is estimated at 1,600,000 tons per year. All the results of fish products must be able to be distributed and can be used properly, so as to avoid damage that reduces the freshness of the fish.

The company's supply of Skipjack is in the form of fresh fish which is then managed to become last longer which is done by freezing fish in cold storage before being distributed (Tummala and Schoenherr, 2011). Skipjack Tuna is one type of fish that is exported and one of the perishable foodstuffs that requires optimal handling so that the exported goods reach the final consumer (Talib, 2017).

One of the Ocean Fishery Ports in Aceh Province is PPS Kutaraja in Banda Aceh city. The dominant catch in PPS Kutaraja in 2017 came from the type of Skipjack Tuna that has the largest percentage of other fish for $46,375 \%$. Complete data on the dominant catches in PPS Kutaraja Banda Aceh, 2017 can be seen in Table 1 as follows. 
Table 1 - Results of Dominant Arrests at PPS Kutaraja Banda Aceh, 2017

\begin{tabular}{cccc}
\hline No & Types of Fish & Production $(\mathrm{Kg})$ & Percentage $(\%)$ \\
\hline 1 & Skipjack Tuna & 6.477 .680 & 46,375 \\
2 & Scad & 3.759 .700 & 26,916 \\
3 & Tuna (Yellow Fin) & 2.298 .743 & 16,457 \\
4 & Bullet Tuna & 234.108 & 1,670 \\
5 & Starry Triggerfish & 212.716 & 1,522 \\
6 & Spotted Sardinella & 126.056 & 0,902 \\
7 & Frigate Mackerel & 190.015 & 1,360 \\
8 & Rainbow Runner & 103.915 & 0,743 \\
9 & Highfin Amberjack & 89.236 & 0,638 \\
10 & Mackerel Tuna & 24.556 & 0,175 \\
\hline
\end{tabular}

Source: Aceh Maritime and Fisheries Office, 2018.

Based on Table 1, it can be seen that in 2017 Skipjack Tuna production ranks first compared to other fish in PPS Kutaraja Banda Aceh, with total $6,477,680 \mathrm{~kg}$. Based on data from the Aceh Marine and Fisheries Service for tuna fish commodity, it shows that the catches of fishermen who experienced a significant increase from 2017 to 2018. Detailed data on the development of Skipjack Tuna can be seen in Table 2 as follows.

Table 2 - Development of Skipjack Tuna Fish Production in Kutaraja PPS 2014-2018

\begin{tabular}{cccc}
\hline No. & Year & Total Production $(\mathrm{Kg})$ & Total Average/Month $(\mathrm{Kg})$ \\
\hline 1 & 2014 & 2.933 .775 & 244.481 \\
2 & 2015 & 3.786 .382 & 315.532 \\
3 & 2016 & 4.451 .764 & 370.980 \\
4 & 2017 & 6.477 .680 & 548.140 \\
5 & 2018 & 7.799 .448 & 649.954 \\
\hline
\end{tabular}

Source: Aceh Maritime and Fisheries Office, 2019.

Based on Table 2, it shows those fishermen's catches are dominant compared to Skipjack Tuna due to the large demand such as in fulfilling supply to the company, so integrated supply chain performance is needed to utilize the production of Skipjack Tuna.

One company that manages Skipjack Tuna is Aceh Lampulo Jaya Bahari Ltd. This company manages fresh Skipjack Tuna from fishermen which is then frozen for immediate distribution. Therefore, the purpose of this study is to determine the product flow, financial flow and information flow of Skipjack Tuna supply at Aceh Lampulo Jaya Bahari Ltd. and to determine the performance of Skipjack Tuna supply at Aceh Lampulo Jaya Bahari Ltd.

\section{METHODS OF RESEARCH}

The location of the research was at PPS Kutaraja Banda Aceh which was devoted to Aceh Lampulo Jaya Bahari Ltd. with commodity types namely Skipjack Tuna. The objects of this study are all parties involved in the Skipjack Tuna supply chain including fishermen, toke bangku (Patron), and Aceh Lampulo Jaya Bahari Ltd. The scope of the study is limited to the problem of Skipjack Tuna supply chain flow and its performance at Aceh Lampulo Jaya Bahari Ltd. This research was conducted from August to December in 2019.

The sampling technique was carried out by interview and direct observation to several stakeholders related to the Skipjack Tuna supply chain activities. More complete types and sources of data can be seen in Table 3 .

The SCOR analysis model has advantages as a Process Reference Model which is the ability to integrate Business Process Reengineering and Overview (Abbaspour, 2019). The output generated from the SCOR method is the performance value matrix of Aceh Lampulo Jaya Bahari Ltd. SCOR is based on five different business processes namely planning, source of supply, production, distribution and return. The definition of attributes and performance can be seen in Table 4. 
Table 3 - Types and Analysis Tools

\begin{tabular}{|c|c|c|c|c|}
\hline \multirow{2}{*}{ No } & \multirow{2}{*}{ Research Purpose } & \multicolumn{2}{|c|}{$\begin{array}{ll}\text { Funding Needs } \\
\end{array}$} & \multirow{2}{*}{ Analysis Tools } \\
\hline & & Primary Data & Secondary Data & \\
\hline 1 & $\begin{array}{l}\text { Describe the supply chain of } \\
\text { skipjack fish, financial flow and } \\
\text { information flow }\end{array}$ & $\begin{array}{l}\text { Interview data on Skipjack } \\
\text { Tuna commodity at Aceh } \\
\text { Lampulo Jaya Bahari Ltd. } \\
\text { 2018, fish distribution and } \\
\text { sales price }\end{array}$ & $\begin{array}{l}\text { Statistics data on Skipjack } \\
\text { Tuna production at PPS } \\
\text { Kutaraja and at Aceh } \\
\text { Lampulo Jaya Bahari Ltd. in } \\
2018 \\
\end{array}$ & Descriptive \\
\hline 2 & $\begin{array}{l}\text { Measuring the performance of } \\
\text { Skipjack Tuna supply chain in } \\
\text { the company including plan, } \\
\text { source, make, deliver and return }\end{array}$ & $\begin{array}{c}\text { Stakeholder assessment of } \\
\text { Aceh Lampulo Jaya Bahari } \\
\text { Ltd. }\end{array}$ & $\begin{array}{l}\text { Statistics on the purchase } \\
\text { and sale of fish at Aceh } \\
\text { Lampulo Jaya Bahari Ltd. in } \\
2018\end{array}$ & $\begin{array}{l}\text { SCOR (Supply } \\
\text { Chain Operation } \\
\text { Reference) }\end{array}$ \\
\hline
\end{tabular}

Source: Prayoga, 2017.

Table 4 - Matrix of Supply Chain Performance Attributes

\begin{tabular}{|c|c|c|c|}
\hline $\begin{array}{l}\text { Core Process } \\
\text { (Level 1) }\end{array}$ & $\begin{array}{l}\text { Dimension } \\
\text { (Level 2) }\end{array}$ & KPI & $\begin{array}{l}\text { Key Performance Indicators } \\
\text { (Level 3) }\end{array}$ \\
\hline \multirow[b]{2}{*}{ Plan } & Reability & P.R.1 & Time to identify employee performance (Days) \\
\hline & Asset & P.A.1 & Cash to cash cycle time (Days) \\
\hline \multirow{4}{*}{ Source } & Reability & $\begin{array}{l}\text { S.R.1 } \\
\text { S.R.2 }\end{array}$ & $\begin{array}{l}\text { Raw materials that are not good }(\mathrm{Kg}) \\
\text { Fulfillment of raw materials }(\mathrm{Kg})\end{array}$ \\
\hline & Responsiveness & S.Re.1 & Receive product cycle time (Days/Tons) \\
\hline & Flexibility & S.F.1 & Supply chain flexibility and adaptability (\%) \\
\hline & Cost & S.C.1 & Cost to source (IDR/Kg) \\
\hline \multirow[t]{3}{*}{ Make } & Reability & $\begin{array}{l}\text { M.R.1 } \\
\text { M.R.2 } \\
\text { M.R.3 }\end{array}$ & $\begin{array}{c}\text { Errors in packaging (Kg) } \\
\text { Total amount of production (Kg/Days) } \\
\text { Total production of employees (Kg/Hour) }\end{array}$ \\
\hline & Responsiveness & M.Re.1 & Production time (Days) \\
\hline & Cost & M.C.1 & Cost to make (IDR/Kg) \\
\hline \multirow[t]{3}{*}{ Deliver } & Reability & $\begin{array}{l}\text { D.R.1 } \\
\text { D.R.2 } \\
\text { D.R.3 }\end{array}$ & $\begin{array}{c}\text { Perfect condition (\%) } \\
\text { Documentation accuracy (\%) } \\
\text { Deliver cycle time (Days) }\end{array}$ \\
\hline & Responsiveness & D.Re.1 & Average document processing time (Days) \\
\hline & Cost & D.C.1 & Cost to deliver (IDR/Kg) \\
\hline Return & Reability & R.R.1 & Return (Kg) \\
\hline
\end{tabular}

Source: Supply Chain Council, 2006.

If the results of an analysis have been obtained, the results will be scored based on a performance indicator monitoring system that can be seen in the following Table 5.

Table 5 - Supply Chain Performance Indicator Monitoring System

\begin{tabular}{cc}
\hline Monitoring & Performance Indicators \\
\hline$<40$ & Poor \\
$40-50$ & Marginal \\
$50-70$ & Average \\
$70-90$ & Good \\
$>90$ & Excellent \\
\hline
\end{tabular}

Source: Trienekens and Hvolby, 2000.

Analytical Hierarchy Process (AHP) is a decision support model developed by Thomas L. Saaty. AHP has the advantage of being able to combine objective elements with subjective elements of a problem (Anjomshoae et al, 2019). The purpose of weighting the AHP is as a model that supports decision making by comparing between elements (Gunduz and Khaled, 2020). An example of weighting can be seen in Table 6.

Table 6 - Pairwise Comparison Matrix

\begin{tabular}{ccccc}
\hline C & A1 & A2 & A3 & An \\
A1 & A11 & A12 & A13 & A1n \\
A2 & A21 & A22 & A23 & A2n \\
A3 & A31 & A32 & A33 & Ann \\
An & An1 & An2 & An3 & Ann \\
\hline
\end{tabular}

Source: Saaty and Vargas, 2000. 
Alternative choices are obtained after weighting and the final value can be seen from the calculation results on priority vector as priority of the weighting results (Kuzu and Beysehir, 2020). After obtaining AHP weights, it is necessary to test the consistency of the type of accurate measurement. The Consistency Index $(\mathrm{Cl})$ formula is:

$$
\mathrm{Cl}=\frac{\lambda m a k s-n}{(n-1)}=\quad \text { (1) (Wibisono, 2006) }
$$

Where: $\lambda$ is eigenvalue and $n$ is the size of the matrix. The maximum eigenvalue of a matrix will not be smaller than the value of $n$ so that the $\mathrm{Cl}$ value is not negative.

The formula of the Random Index is as follows.

$$
\mathrm{RI}=\frac{1.98(n-2)}{(n)}=\quad \text { (2) }(\text { Wibisono, 2006) }
$$

The formula for the Consistency Ratio is as follows.

$$
\mathrm{CR}=\frac{(C I)}{(R I)} \quad \text { (3) (Wibisono, 2006) }
$$

Where: Cl - Consistency Ratio; RI - Consistency Index; CR - Random Index.

If the CR is greater than 0.10 or equal to $10 \%$, it means that each element that has been determined is not compared to the proper and the decision maker must review the comparison process carried out (Wibisono, 2006).

OMAX (Objective Matrix) can combine several productivity criteria into an integrated form and related to each other. The OMAX assessment scheme consists of three parts: very low (red), mid (yellow) and very good (green) shown in Table 7 as follows.

Table 7 - Examples of OMAX (Objective Matrix) Schemes

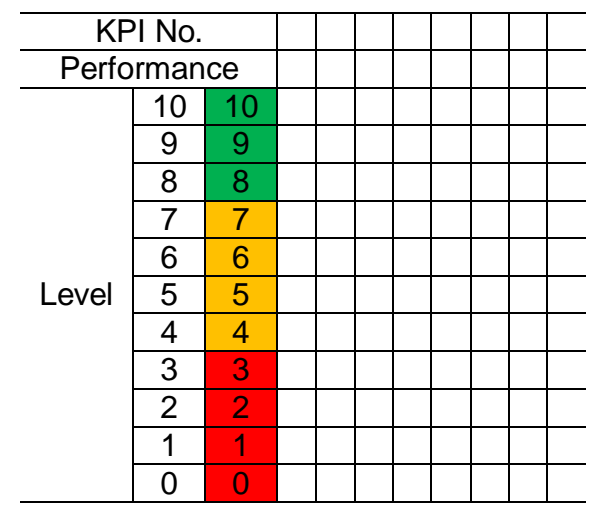

Source: Riggs, 1987.

A standard performance value can be obtained from the calculation of the average that will be placed at level 3 . After level 3 is filled, then determine the smallest scale of the calculation of the ratio that will be placed at level 0 . For level 10 is the value of the target to be achieved by the company (Avianda et al, 2014). The formula used to calculate the scale between level 0 to level 3 with the following formulation:

$$
\text { Level } 0 \text {-Level } 3=\frac{(\text { Level 3-Level 0) }}{(3-0)} \quad \text { (1) (Avianda et al, 2014) }
$$

The formula used to calculate the scale between level 3 and level 10 is as follows:

$$
\text { Level 3-Level } 10=\frac{(\text { Level 10-Level 3) }}{(10-3)} \quad \text { (2) (Avianda et al, 2014) }
$$




\section{RESULTS AND DISCUSSION}

The potential of Skipjack Tuna production is influenced by the type of fishing gear used. There are 3 types of fishing gear used in the Ocean Fisheries Port (PPS) of Kutaraja, namely Purse Seine, Ulur Fishing Line and Rawai Fishing Line. Purse Seine fishing gear is a fishing gear that has the biggest catch landed at PPS Kutaraja. One of the companies established in the area of PPS Kutaraja is Aceh Lampulo Jaya Bahari Ltd. as a company that manages fish by freezing it in cold storage with a capacity of 400 tons. Aceh Lampulo Jaya Bahari Ltd. has a concept of performance that is very concerned with the quality of the product.

The concept of supply chain is a system that is complexly used (Ganesan et al, 2020). The supply chain system must also be managed properly to become a unified and sustainable whole (Krishnan et al, 2020). There are 3 integrated supply chain systems, which include physical flow, financial flow and information flow (Pellegrino et al, 2018). The three flows in PPS Kutaraja can be seen in Figure 1 as follows.

Maritime and Fisheries Service, Fishermen/Producers, toke bangku (Patron), Aceh Lampulo Jaya Bahari Ltd, Local Retailers, Regional, Medan Tropical Canning Ltd. Export, Final Consumer.

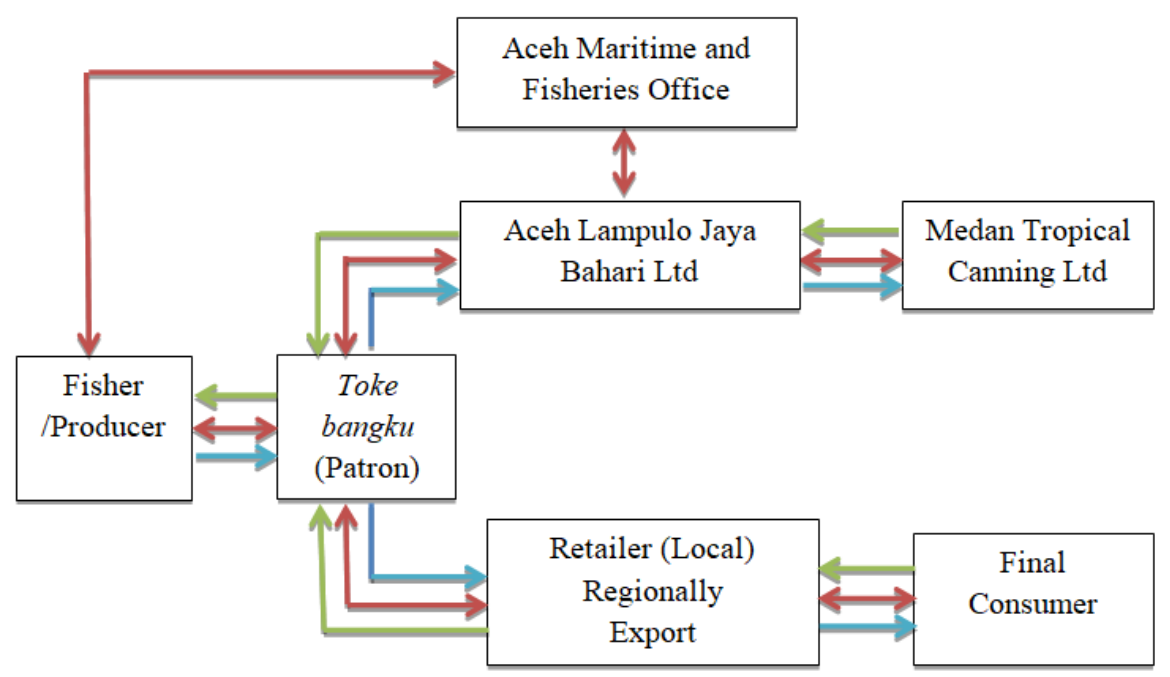

Physical Flow of Skipjack Tuna Information Flow of Skipjack Tuna

Financial Flow of Skipjack Tuna

Figure 1 - Physical Flow Scheme, Information Flow and Financial Flow

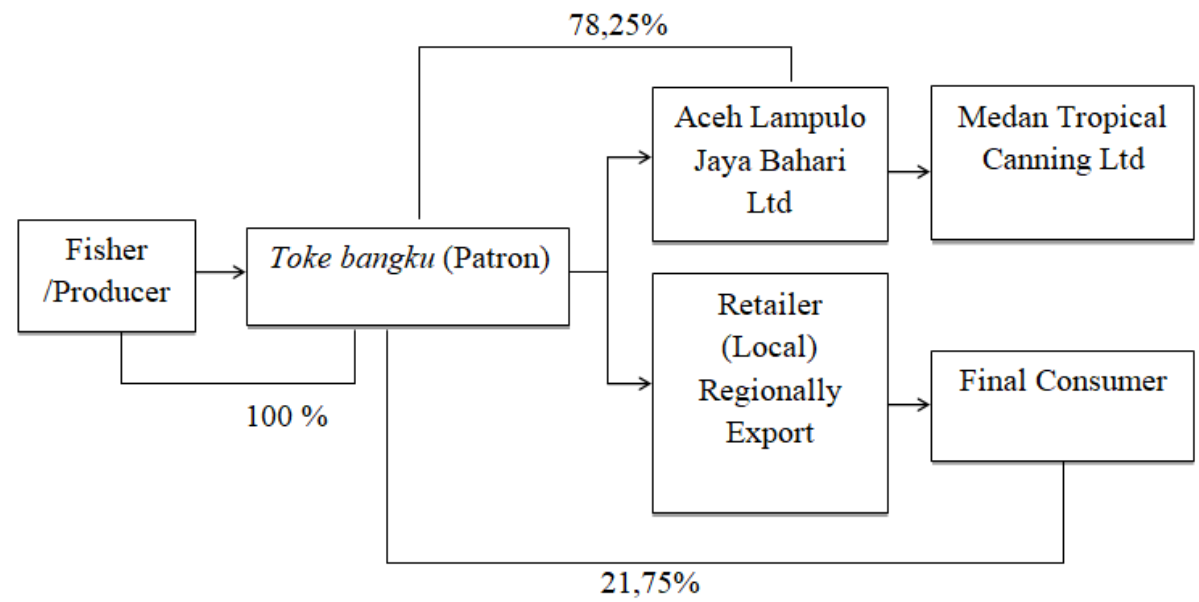

Figure 2 - Scheme of Skipjack Tuna supply chain 
Figure 1 shows that the physical flow (product) of Skipjack Tuna is starting from fishermen selling fish through toke bangku (Patron); toke bangku (Patron) sell it to Aceh Lampulo Jaya Bahari Ltd., local and regional retailers, and then export to final consumers. The information flow was obtained from PPS Kutaraja area which was under the supervision of the Aceh Marine and Fisheries Service. The Skipjack Tuna supply chain flow can be seen in Figure 2.

Based on Figure 2, it can be seen that the production of fresh Skipjack Tuna in PPS Kutaraja which is sold through toke bangku (Patron) reaching $100 \%$, but toke bangku (Patron) do not sell all Skipjack Tuna to the company. The company gets the supply of Skipjack Tuna only $78.25 \%$. Toke bangku (Patron) also sell Skipjack Tuna fish to regional retailers and export reaching $21.75 \%$ and the last distribution is directly sent to final consumers. Toke bangku (Patron) benefits from the sale of Skipjack Tuna by selling it to Aceh Lampulo Jaya Bahari Ltd., then Aceh Lampulo Jaya Bahari Ltd. sends the frozen tuna to Medan Tropical Canning Ltd. without additional value due to the co-partnership of both companies.

There are 18 dominant and most important indicators that will be measured at Aceh Lampulo Jaya Bahari Ltd. which is the main focus in the company's performance and the indicators have been confirmed to avoid repetition. The selected indicator is an indicator that matches the needs of the company. These KPIs can be seen in Table 8 as follows.

Table 8 - Matrix of Supply Chain Performance Attributes and Weighting Results

\begin{tabular}{|c|c|c|c|c|c|c|}
\hline $\begin{array}{l}\text { Core } \\
\text { Process } \\
\text { (Level 1) }\end{array}$ & Weight & $\begin{array}{l}\text { Dimension } \\
\text { (Level 2) }\end{array}$ & Weight & $\mathrm{KPI}$ & $\begin{array}{l}\text { Key Performance Indicators } \\
\text { (Level 3) }\end{array}$ & Weight \\
\hline \multirow[t]{2}{*}{ Plan } & \multirow{2}{*}{0,04} & Reability & 0,67 & P.R.1 & $\begin{array}{l}\text { Time to identify } \\
\text { performance }\end{array}$ & 1,00 \\
\hline & & Asset & 0,33 & P.A.1 & Cash to cash cycle time & 1,00 \\
\hline \multirow{4}{*}{ Source } & \multirow{4}{*}{0,51} & Reability & 0,30 & $\begin{array}{l}\text { S.R.1 } \\
\text { S.R.2 }\end{array}$ & $\begin{array}{l}\text { Raw materials that are not good } \\
\text { Fulfillment of raw materials }\end{array}$ & $\begin{array}{l}0,75 \\
0,25\end{array}$ \\
\hline & & Responsiveness & 0,10 & S.Re.1 & Receive product cycle time & 1,00 \\
\hline & & Flexibility & 0,09 & S.F.1 & Supply chain flexibility and adaptability & 1,00 \\
\hline & & Cost & 0,50 & S.C.1 & Cost to source & 1,00 \\
\hline \multirow[t]{3}{*}{ Make } & \multirow[t]{3}{*}{0,26} & Reability & 0,27 & $\begin{array}{l}\text { M.R.1 } \\
\text { M.R.2 } \\
\text { M.R.3 }\end{array}$ & $\begin{array}{l}\text { Errors in packaging } \\
\text { Total amount of production } \\
\text { Total production of employees }\end{array}$ & $\begin{array}{l}0,71 \\
0,14 \\
0,14\end{array}$ \\
\hline & & Responsiveness & 0,09 & M.Re.1 & Production time & 1,00 \\
\hline & & Cost & 0,64 & M.C.1 & Cost to make & 1,00 \\
\hline \multirow[t]{3}{*}{ Deliver } & \multirow[t]{3}{*}{0,12} & Reability & 0,27 & $\begin{array}{l}\text { D.R.1 } \\
\text { D.R.2 } \\
\text { D.R.3 }\end{array}$ & $\begin{array}{l}\text { Perfect condition } \\
\text { Documentation accuracy } \\
\text { Delivery cycle time } \\
\end{array}$ & $\begin{array}{l}0,75 \\
0,12 \\
0,13 \\
\end{array}$ \\
\hline & & Responsiveness & 0,09 & D.Re.1 & Average document processing time & 1,00 \\
\hline & & Cost & 0,64 & D.C.1 & Cost to deliver & 1,00 \\
\hline Return & 0,07 & Reability & 1 & R.R.1 & Return & 1,00 \\
\hline
\end{tabular}

Source: Primary Data (processed), 2019.

Table 8 above shows that in the core process the source weight value is the greatest weight with a score of 0.51 or $51 \%$ compared to the plan that is 0.04 or $4 \%$, make as much as 0.26 or $26 \%$, deliver as much as 0,12 or $12 \%$ and return of 0.07 or $7 \%$. Based on the results of the calculation, the source has the greatest weight, meaning that among several other core processes the core source process is the main priority that is most needed by the company Aceh Lampulo Jaya Bahari Ltd. The smallest weight is in the core plan process, which means that Aceh Lampulo Jaya Bahari Ltd. is not planning for the skipjack tuna supply chain.

Objective Matrix Analysis (OMAX) is an analytical method used to assess all company activities (James L. Riggs, 1986). Scoring System calculations are performed using the Objective Matrix (OMAX) method. The results of the Scoring System calculation conducted at Aceh Lampulo Jaya Bahari Ltd. can be seen in Table 9. 
Table 9 - Matrix Scoring System Perspective Plan

\begin{tabular}{|c|c|c|c|}
\hline & & P.R.1 & P.A.1 \\
\hline \multirow{11}{*}{ Level } & 10 & 2,00 & 11,47 \\
\hline & 9 & 2,12 & 12,40 \\
\hline & 8 & 2,25 & 13,32 \\
\hline & 7 & 2,37 & 14,25 \\
\hline & 6 & 2,49 & 15,17 \\
\hline & 5 & 2,61 & 16,10 \\
\hline & 4 & 2,74 & 17,02 \\
\hline & 3 & 2,86 & 17,95 \\
\hline & 2 & 3,14 & 21,07 \\
\hline & 1 & 3,43 & 24,20 \\
\hline & 0 & 3,71 & 27,32 \\
\hline \multicolumn{2}{|c|}{ Level } & 3,92 & 4,00 \\
\hline \multicolumn{2}{|c|}{ Weight } & 1,00 & 1,00 \\
\hline \multicolumn{2}{|c|}{ Value } & 3,92 & 4,00 \\
\hline
\end{tabular}

Source: Primary Data (processed), 2019.

Based on Table 9 it can be seen that the value of the perspective plan scoring system on KPI P.R.1 has a value of 3.92 that is in the red zone or in the poor category, which means that Aceh Lampulo Jaya Ltd. must re-evaluate its performance system in order to achieve the company's target. Meanwhile, for KPI P.A.1, the company gets a score of 4.00 in the yellow zone, which means the company must also be careful so that its performance will not decrease.

Table 10 - Matrix of Perspective Source Scoring System

\begin{tabular}{|c|c|c|c|c|c|c|}
\hline \multicolumn{2}{|c|}{ KPI No } & S.R.1 & S.R.2 & S.Re.1 & S.F.1 & S.C.1 \\
\hline \multirow{11}{*}{ Level } & 10 & 0 & 789.600 & 0,033 & 100 & 14.000 \\
\hline & 9 & 10 & 508.612 & 0,036 & 93,79 & 14.417 \\
\hline & 8 & 20 & 508.612 & 0,040 & 87,57 & 14.833 \\
\hline & 7 & 30 & 508.612 & 0,043 & 81,36 & 15.250 \\
\hline & 6 & 40 & 508.612 & 0,046 & 75,15 & 15.666 \\
\hline & 5 & 50 & 508.612 & 0,049 & 68,94 & 16.083 \\
\hline & 4 & 60 & 508.612 & 0,053 & 62,72 & 16.499 \\
\hline & 3 & 70 & 508.612 & 0,056 & 56,51 & 16.916 \\
\hline & 2 & 80 & 314.030 & 0,065 & 49,30 & 19.277 \\
\hline & 1 & 90 & 314.030 & 0,074 & 42,10 & 21.639 \\
\hline & 0 & 100 & 314.030 & 0,083 & 34,89 & 24.000 \\
\hline \multicolumn{2}{|c|}{ Level } & 10 & 4,00 & 4,17 & 3,83 & 4,75 \\
\hline \multicolumn{2}{|c|}{ Weight } & 0,75 & 0,25 & 1 & 1 & 1 \\
\hline \multicolumn{2}{|c|}{ Value } & 7,5 & 1 & 4,17 & 3,83 & 4,75 \\
\hline
\end{tabular}

Source: Primary Data (processed), 2019.

Based on Table 10 it can be seen as a whole that for S.F.1, the company has not been able to perform its performance optimally because it is still in the red zone and there needs to be an evaluation or a review of its performance.

Table 11 - Matrix Scoring System Perspective Make

\begin{tabular}{|c|c|c|c|c|c|c|}
\hline \multicolumn{2}{|c|}{$\mathrm{KPI}$ No } & M.R.1 & M.R.2 & M.R.3 & M.Re.1 & M.C.1 \\
\hline \multirow{11}{*}{ Level } & 10 & 0 & 27.000 & 9.000 & 3 & 304,51 \\
\hline & 9 & 10 & 16.718 & 5.573 & 4 & 338,16 \\
\hline & 8 & 20 & 16.718 & 5.573 & 5 & 371,81 \\
\hline & 7 & 30 & 16.718 & 5.573 & 6 & 405,46 \\
\hline & 6 & 40 & 16.718 & 5.573 & 7 & 439,11 \\
\hline & 5 & 50 & 16.718 & 5.573 & 8 & 472,76 \\
\hline & 4 & 60 & 16.718 & 5.573 & 9 & 506,41 \\
\hline & 3 & 70 & 16.718 & 5.573 & 10 & 540,06 \\
\hline & 2 & 80 & 9.677 & 3.226 & 11 & 643,24 \\
\hline & 1 & 90 & 9.677 & 3.226 & 12 & 746,42 \\
\hline & 0 & 100 & 9.677 & 3.226 & 13 & 849,60 \\
\hline \multicolumn{2}{|c|}{ Level } & 10 & 3,83 & 3,83 & 10 & 3,92 \\
\hline \multicolumn{2}{|c|}{ Weight } & 0,71 & 0,14 & 0,14 & 1 & 1 \\
\hline \multicolumn{2}{|c|}{ Value } & 7,1 & 0,53 & 0,53 & 10 & 3,92 \\
\hline
\end{tabular}

Source: Primary Data (processed), 2019. 
Based on Table 11 above, it can be seen that the company's performance for M.R.1 and M.Re. 1 is good, that is in the green zone, that is, the company has never made mistakes in packing frozen tuna products and the company also has efficient production time. For the performance of M.R.2, M.R.3 and M.C.1 performance evaluations and improvements are still needed.

Table 12 - Deliver Perspective Scoring Matrix System

\begin{tabular}{|c|c|c|c|c|c|c|}
\hline \multicolumn{2}{|c|}{ KPI No } & D.R.1 & D.R.2 & D.R.3 & D.Re.1 & D.C. 1 \\
\hline \multirow{11}{*}{ Level } & 10 & 100 & 100 & 1 & 1 & 300 \\
\hline & 9 & 99 & 99 & 2 & 2 & 400 \\
\hline & 8 & 98 & 98 & 3 & 3 & 500 \\
\hline & 7 & 97 & 97 & 4 & 4 & 600 \\
\hline & 6 & 96 & 96 & 5 & 5 & 700 \\
\hline & 5 & 95 & 95 & 6 & 6 & 800 \\
\hline & 4 & 94 & 94 & 7 & 7 & 900 \\
\hline & 3 & 93 & 93 & 8 & 8 & 1000 \\
\hline & 2 & 92 & 92 & 9 & 9 & 1100 \\
\hline & 1 & 91 & 91 & 10 & 10 & 1200 \\
\hline & 0 & 90 & 90 & 11 & 11 & 1300 \\
\hline \multicolumn{2}{|c|}{ Level } & 10 & 10 & 10 & 10 & 10 \\
\hline \multicolumn{2}{|c|}{ Weight } & 0,75 & 0,12 & 0,13 & 1 & 1 \\
\hline \multicolumn{2}{|c|}{ Value } & 7,5 & 1,2 & 1,3 & 10 & 10 \\
\hline
\end{tabular}

Source: Primary Data (processed), 2019.

Table 13 - The Return Perspective Scoring System Matrix

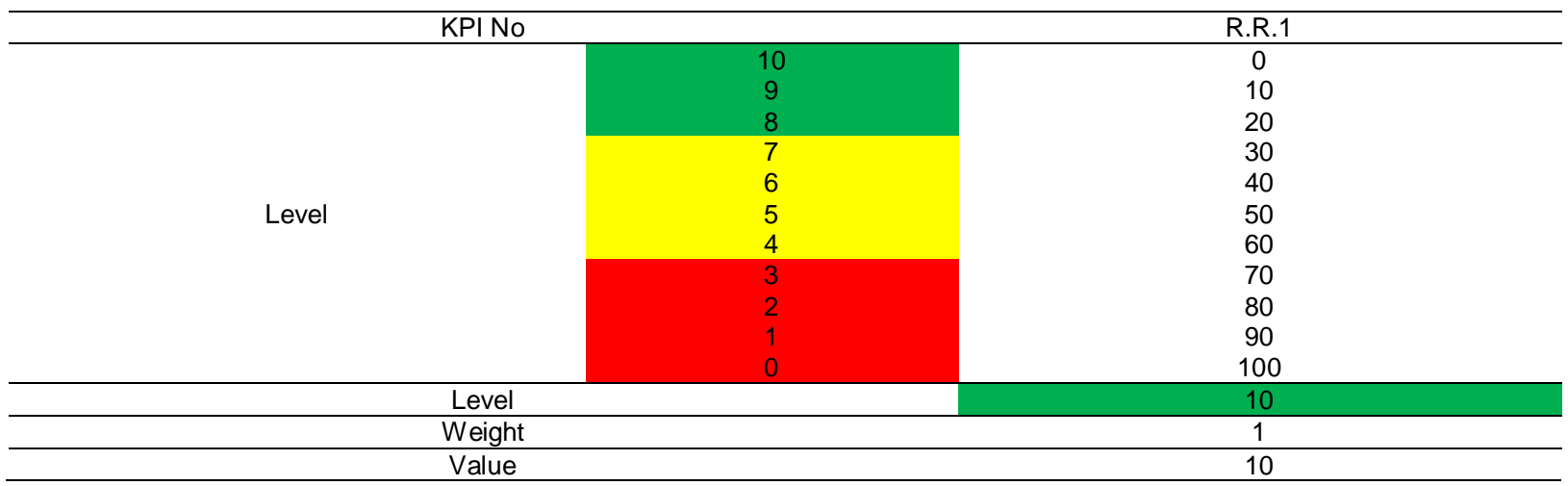

Source: Primary Data (processed), 2019.

Table 14 - Performance Measurement Matrix at Aceh Lampulo Jaya Bahari Ltd. in 2018

\begin{tabular}{|c|c|c|c|c|}
\hline No & Perspective & Dimension & \multicolumn{2}{|c|}{ KPI } \\
\hline \multirow{2}{*}{1} & & Reability $(3,92)$ & P.R.1 & 3,92 \\
\hline & PIan $(3,95)$ & Asset (4) & P.A.1 & 4 \\
\hline \multirow{5}{*}{2} & \multirow{5}{*}{ Source $(5,69)$} & & S.R.1 & 10 \\
\hline & & Reabllity $(8,50)$ & S.R.2 & 4 \\
\hline & & Responsivenees $(4,17)$ & S.Re.1 & 4,17 \\
\hline & & flexibility $(3,83)$ & S.F.1 & 3,83 \\
\hline & & Cost $(4,75)$ & S.C.1 & 4,75 \\
\hline \multirow{5}{*}{3} & \multirow{5}{*}{ Make $(5,61)$} & & M.R.1 & 10 \\
\hline & & Reability (8.16) & M.R.2 & 3,83 \\
\hline & & & M.R.3 & 3,83 \\
\hline & & Responsivenees (10) & M.Re.1 & 10 \\
\hline & & Cost $(3,92)$ & M.C.1 & 3,92 \\
\hline \multirow{5}{*}{4} & \multirow{5}{*}{ Deliver (10) } & & D.R.1 & 10 \\
\hline & & Reability (10) & D.R.2 & 10 \\
\hline & & & D.R.3 & 10 \\
\hline & & Responsivenees (10) & D.Re.1 & 10 \\
\hline & & Cost (10) & D.C.1 & 10 \\
\hline 5 & Return (10) & Reability (10) & R.R.1 & 10 \\
\hline & & Index Total & & \\
\hline
\end{tabular}

Source: Primary Data (processed), 2019. 
Based on Table 12, it can be seen that the performance of Aceh Lampulo Jaya Bahari Ltd. in the perspective of deliver is already meeting the target and is in the green zone.

Based on Table 13, it can be seen that for the performance of the performance perspective scoring system, the company is in the green zone because there is no return.

Based on Table 14 above, it can be seen that the overall performance calculation of Aceh Lampulo Jaya Bahari Ltd. obtained a total index score of 6.42 and the value is in the yellow zone. PT Aceh Lampulo Jaya Bahari must improve or evaluate some of the performance in the red and yellow zones to improve company performance. The performance indicator monitoring system at Aceh Lampulo Jaya Bahari Ltd. can be seen in Table 15 as follows.

Table 15 - Monitoring System Performance Indicators of Aceh Lampulo Jaya Bahari Ltd. in 2018

\begin{tabular}{cc}
\hline Monitoring & Performance Indicators \\
\hline$<40$ & Poor \\
$40-50$ & Marginal \\
$50-70$ & Average \\
$70-90$ & Good \\
$>90$ & Excellent \\
\hline
\end{tabular}

Source: Primary Data (processed), 2019.

Measurement of supply chain performance in researched companies refers to Trienekens and Hvolby (2000) standards. Based on Table 15 above, the results of the performance of Aceh Lampulo Jaya Bahari Ltd. are on the performance indicator is the average and the index value of the total performance of the Skipjack Tuna supply chain at Aceh Lampulo Jaya Bahari Ltd. is 6,42 on a scale of 10 or 64,2 on a scale of 100 .

\section{CONCLUSION}

Product flow and information flow at Aceh Lampulo Jaya Bahari Ltd. is still not optimal due to the lack of supply raw materials planning, seen from the amount of raw material for fresh Skipjack Tuna still not meeting the target. The company's raw material target is 30,000 $\mathrm{kg}$ per day, but the amount of Skipjack Tuna is always below the company's target. Fresh Skipjack Tuna is not fully sold to Aceh Lampulo Jaya Bahari Ltd. by toke bangku (Patron) because of limited information on the amount of raw material needed by the company per day that causes some fresh Skipjack Tuna sold outside the region. The flow of finance at Aceh Lampulo Jaya Bahari Ltd. is also still not optimal due to the long waiting period between payments made by Medan Tropical Canning Ltd. to Aceh Lampulo Jaya Bahari Ltd.

The results of supply chain performance measurements at Aceh Lampulo Jaya Bahari Ltd. Showed that there are $5 \mathrm{KPIs}$ which categorized poor, namely PR1, SF1, MR2, MR3 and $\mathrm{MC1}$. The company pays little attention to these indicators so that these indicators must immediately take action in making improvements to improve company performance to meet so the company targets. The total performance value of Aceh Lampulo Jaya Bahari Ltd. is in the average category with a total index value reaching 64,2 . The company is not in a safe position because a few mistakes can reduce the company's performance.

\section{REFERENCES}

1. Abbaspour, A. 2019. Supply Chain Analysis and Improvement by Using the SCOR Model and Fuzzy AHP: A Case Study. International Journal of Industrial Engineering \& Management Science. 6 (2): 51-73.

2. Anjomshoae, A., Kuan, Y.W and Adnan, H. 2019. An Integrated AHP-Based Scheme for Performance Measurement in Humanitarian Supply Chains". International Journal of Productivity and Performance Management, https:// doi.org.10.1108/IJPPM-04-20180132. 
3. Athaillah, T., Ahmad, H.H and Indra. 2018. Analisis Rantai Pasok (Supply Chain) Ikan Tuna pada CV Tuah Bahari and PT Nagata Prima Tuna di Banda Aceh. Marine Fisheries. 9 (2): 169-181.

4. Avianda, D., Yoanita, $Y$ and Yuniar. 2014. Strategi Peningkatan Produktivitas di Lantai Produksi Menggunakan Metode Objective Matrix (OMAX). Jurnal Online Institut Teknologi Nasional. 4 (1).

5. Ganesan., Pandian, V and Igor, S.L. 2020. Multiobjective Optimization of a Biofuel Supply Chain Using Random Matrix Generators. Universitas Teknologi PETRONAS Malaysia, https://doi.org/ 10.4018/978-1-7998-1192-3.ch013.

6. Gunduz, M and Khaled, O.M. 2020. Assessment Of Change Order Impact Factors On Construction Project Performance Using Analytic Hierarchy Process (Ahp). Technological and Economic Development of Economy. 26 (1): 71-85.

7. Husna, N., Akhmad, B and Romano. 2018. Analisis Rantai Pasokan Dengan Pendekatan Penyediaan Bahan Baku (Inventori) Pada Pengolahan Kopi Arabika Di Kabupaten Aceh Tengah. Jurnal Ilmiah Mahasiswa Pertanian Unsyiah. 3 (2).

8. Kasimin, S. 2013. Keterkaitan Produk and Pelaku Dalam Pengembangan Agribisnis Hortikultura Unggulan di Provinsi Aceh. Jurnal Manajemen and Agribisnis. 10 (2).

9. Krishnan, R., Renu, A., Christopher, B., and K.Arshinder. 2020. Redesigning a Food Supply Chain for environmental suitainability - An Analysis of Resource Use and Recovery. Science Direct. Journal of Cleaner Production. 242 (1).

10. Kuzu, O.H and Beysehir, A.H. 2020. Strategy Selection In The Universities Via Fuzzy AHP Method:A Case Study. International Journal of Higher Education. 9 (2).

11. Pellegrino, R.,Nicola, C and Danilo, T. 2018. Journal of Purchasing and Supply Management https://doi.org/10.1016/j.pursup.2018.03.004.

12. Prayoga, M.Y. 2017. Rantai Pasok Ikan Tuna and Cakalang. Tesis. Sekolah Pasca Sarjana, Institut Pertanian Bogor, Bogor.

13. Riggs, J.L. 1987. Production System Planning, Analysis and Control. John Wiley and Sons Inc. Singapore.

14. Saaty, T. L., and Vargas, L. G. 2000. Model, Method, Concepts \& Applications of the Analytical Hierarcy Process. New York: Springer Science Business Media.

15. Sulaeman, M., Kornelius, $Y$ and Darman. 2018. Analysis of Fish Supply Chains in Tomini Bay Area, Indonesia. Russian Journal of Agricultural and Socio-Economic Sciences (RJOAS). 10 (82): 268-271.

16. Sutrisno, A., Vikas, K., Dwi, H., Rudi, K.A., Shinta, V and Charles, P. 2019. Categorization of Supply Chain Sustainability Risks in SMEs: A Preliminary evidence from a Developing Country. Proceedings of the International Conference on Industrial Engineering and Operations Management Pilsen, Czech Republic, 23-26.

17. Talib, A. 2017. Tuna and Cakalang (Suatu Tinjauan: Pengelolaan Potensi Sumberdaya Di Perairan Indonesia). Jurnal IImiah agribisnis and Perikanan (agrikan UMMU-Ternate). 10 (1).

18. Toding, J.D.G., Arrazi, B.H.J and Jacky, S.B.S. 2019. Identifikasi and Efisiensi Kinerja Rantai Pasok Ikan Cakalang Di Tanawangko Kabupaten Minahasa. Jurnal EMBA. 7 (1): Hal. $391-400$.

19. Trienekens, J and Hvolby, H. 2000. Performance Measurement And Improvement Supply Chain. CINet Conference Cl2000 from Improvement to Innovation (pp.399- 408). Aalborg: Aalborg University.

20. Tummala, R., and Schoenherr, T. 2011. Assessing and Managing Risk Using The Supply Chain Risk Management Process (SCRMP). Supply Chain Management: An International Journal, 474-483.

21. Wibisono, D. 2006. Manajemen Kinerja: Konsep Desain and Teknik meningkatkan Daya Saing Perusahaan. Jakarta: Erlangga. 